\title{
COMPREHENSION OF THE DESIGN PROCESS IN TEACHER EDUCATION
}

\author{
Māra Urdziṇa-Deruma, Mārīte Kokina-Lilo \\ University of Latvia, Latvia
}

\begin{abstract}
Design and technologies are being introduced as a new general education school subject in Latvia instead of the home economics and technologies subject. However, the main focus in the new subject is on comprehending the process of design and design thinking, there is little research done on how to teach the design process in general education and no research on how to teach design process for future teachers of design and technologies in Latvia. Many scholars pay attention to the process of design and teaching it. In this study, the authors have researched several studies on the design process types and components. The research question was formulated as follows: What kind of problems could arise when implementing the concept of the design process in teacher education. The pilot research was carried out in two student groups ( $\mathrm{N} 1=28 ; \mathrm{N} 2=12)$. The method of analyzing student's diaries' content was applied. The diaries were analyzed according to van Dooren and colleagues' (2014) theory of generic elements in the design process. It was concluded that students prefer to use a guiding theme and domains. The main domains in students' opinion are product materials, form and space, and color. As the most important characteristics of the products in students' opinion are technical quality, product functionality, and creativity. Internet resources and books were the most commonly used resources. Students could pay more attention to documenting the design process and sketching and evaluate other criteria of the product quality. The obtained results will be taken into account in the teaching process and the future research of the design process acquired in teacher education.
\end{abstract}

Keywords: design and technologies, design process, generic elements in the design process, phases of the design process, product design, teacher education.

\section{Introduction}

In the newly introduced teaching subject design and technologies instead of home economics and technologies in the general education in Latvia, the main focus is on the design process and design thinking. Many scholars pay attention to the design process and teaching of the design process. Van Dooren and colleagues (2014) have researched the design process in design teacher studies, Porko-Hudd and colleagues (2018) have studied 
the design process in craft subjects in Finland, Aflatoony and colleagues (2018a, b) have presented results of their research in Canada secondary schools. Dazkir and colleagues (2013) have illustrated the inspiration process in designer studies, Sawyer (2018) has researched the creative process in art and design studies. In this study, the authors researched several scholars' opinions on the design process types and components and their connection. The aim is to find the optimal approach for the teachers' education of design and technologies.

\section{Literature review}

If we compare the previous teaching subject home economics and technologies with the new subject design and technologies in Latvia, one of the main differences in the activities of the students is that the old subject focuses on the creative activity, which starts with an idea, then continues with the visualization of the idea, making of the product and ends with an evaluation, whereas in the newly introduced subject the focus is on the design process, which includes such sub-activities as identifying needs and opportunities, finding ideas and choosing a solution, planning, making, assessing, testing, developing and implementing (Noteikumi par valsts pamatizglïtības standartu, pamatizglìtỉbas mācību priekšmetu standartiem un pamatizglïtības programmu paraugiem, 2014; Noteikumi par valsts pamatizglitības standartu un pamatizglitîbas programmu paraugiem, 2018).

Porko-Hudd and colleagues $(2018,34)$ consider that craft, design, and technology education is a channel through which people can see the potential of sustainable consumption and how they can develop their skills and make something specific. It is the possibility to make sustainable products for specific needs, which are "meaningful, aesthetic, of good quality and made for the need and aim to increase well-being from the beginning of basic education". Hur and Beverley (2013) highlight that craft has a significant role in developing a sustainable design. Aflatoony and colleagues (2018b) describe design thinking as a collaborative, problem solving, and human-centric approach. Designing can be seen also as a complex, personal, creative, and open-ended skill (van Dooren et al., 2014). As Sawyer (2018) points out, a cultural model of teaching and learning in both design and art schools is the studio model, where the central concept is the creative process.

Freimane (2015a) concludes that primary school pupils can acquire design thinking, creating design products, and design process training methods successfully. The findings of Freimane (2015a, b) illustrate that the development of empathy, systemic thinking, respect of purpose, visual imagery and associative thinking, performance modelling, craft skills, and the impact of technology is necessary to democratize design thinking. 
Hasso Plattner Institute of Design at Stanford (2011), Doorley and colleagues (2018) suggest a five-step design process inviting to empathize, define, ideate, prototype, and test. It offers several teaching and learning methods. In this approach, the focus is on empathy - understanding people for whom the design is created. Aflatoony and colleagues (2018b) use this approach, and their findings show that the teacher has to evaluate four main characteristics when students are designing a new product: design terminology, steps of the design process, focus on the first four steps, improved knowledge. They also consider that during the course students pay more attention to the user's feelings and problems, and their empathy is being developed. The authors indicate different levels of group work describing the issues, for instance, a problem of equal collaboration, time management, concentration as well as a leadership problem. The authors examine students' homework: concluding the design process, they consider that students have different understandings of the design process. For example, some students miss certain steps, some do not understand the necessity to define the problem, etc.

Carroll and colleagues (2010) clarify that the design thinking process consists of the following phases: understanding, observing, setting point of view, ideating, prototyping, and testing. During the first phase, students research different sources related to design issues. In the second phase, students observe how people behave and interact, ask them questions, and reflect. During the first two phases, students develop empathy. During the third phase, setting a point of view, students synthesize what they learned before. In the ideating phase, students generate many different ideas. Prototyping is making sketches or two- or three-dimensional objects. In the testing phase, students conclude what works and what doesn't on user feedback basis. Then students can improve the sketch or the object. The authors see the design thinking process as exploring, connecting, and intersecting.

McLachlan and colleagues (n.d.) indicate eight stages in the design process: define, identify, brainstorm, select, prototype, test, iterate, communicate which is most similar approach to those proposed in the new standard and programs for the technology domain of general education in Latvia. (Noteikumi par valsts pamatizglitības standartu un pamatizglītības programmu paraugiem, 2018).

Freimane $(2015 b, 76)$ recommends making a pre-research, where the problem and idea are examined from different perspectives, such as context, possibilities, tendencies, values, needs, aims, and methods of creative thinking, by using literature and analog designs. After that, the design tasks are defined. Then, the research, action plan and visualization are primarily followed, including sketches, interviews, analysis of contexts, 3D, then prototyping, implementing, and the final stage is the completion of the 
product. In her research Freimane $(2015$, b) focuses on the direction of sustainable social welfare of the design process.

Findeli (2001) states that the old understanding of the act of design is as follows: a problem is identified (situation A), and as a result, the solution is imagined and described (situation B). As opposed, he presents a new logical structure of the design process by writing that instead of a problem there is state A of a system, and instead of a solution, there is state B of the system. The designer and the user are part of the system. The designer should understand the dynamic structure of the system.

In design teaching, van Dooren and colleagues (2014) describe five generic elements of the design process: (1) experimenting or exploring and deciding, (2) guiding theme or qualities, (3) domains, (4) frame of reference or library, (5) laboratory or (visual) language - sketching and modelling. An effective secondary school design thinking curriculum includes experiential activities, real-world applications, and characterized consequences (Aflatoony, 2018a). They can be explored by using several teaching methods, such as observation activity, visit of a practicing designer, interview activities, bodystorming in the groups, where the students are acting out scenarios by using role-playing, field trips, reflections, discussions, regular sketching, and analysis of sketches and others. (Aflatoony et al., 2018a) Sketching is not only a way of presenting results. In fact, sketching and modelling make it possible to discover new ideas. The process of sketching often involves discoveries; the thought is different when it becomes concrete in a sketch or model (van Dooren et al., 2014, p. 13; Laamanen, 2012). Bresciani (2019) divides visualization into seven traits: structural, restrictiveness, content modifiability, directed focus, perceived completion, outcome clarity, visual appeal, and collaboration support which affect cognition, communication, and collaboration.

In the teaching of design process James (2017) focuses on students' self-awareness, mindfulness, and cognitive development as well as empathy as opposed to the artefact. She convinces that a person can use only real problems analyzed from different viewpoints. The discussion implies that research, observation, and pausing before any attempt at problem-solving are very important/ cinematic. Reitan (2014) focuses on learning-by-watching to improve design education in both compulsory and academic design education. It would help to create reflective practitioners and more sustainable design.

Dorst and Cross (2001) conclude that analysis, synthesis, and evaluation repeat in the design process according to both the development of the problem and the development of solutions. They consider that ergonomics, technical aspects, business aspects, creativity are the criteria for evaluation of the design process. 
Laamanen (2012) focuses on the idea generation phase in the craft design teaching process for future teachers. She concludes that utility is the basic purpose of craft-making in the craft design process, but there is not enough support for the students in the idea generation phase. Social support and open-ended tasks are necessary for the idea generation step. It is also important to organize working practices that promote self-efficiency and self-generated learning. In her experience, the mind map is a good starting point for idea generation. She emphasizes the importance of collecting visual and material as well as textual sources for the generation of ideas. Dazkir and colleagues (2013) describe the sources of inspiration in the design process for novice design students. Although their research shows that students did not appreciate the provided sources for inspiration and ideas, i. e., cultural values of certain nations and countries, they believe that at the beginning of the design study process the students need an assignment where a specific source of inspiration along with the instructor's guidelines is included.

Hur and Beverley (2013) explain how the designer and user can collaborate in the design process from the very beginning to make sustainable fashion by using idea generation toolkits. The authors demonstrate two ways of doing this: real co-design activities and opportunities to work online.

Graham and colleagues (2007) describe the deterministic design as a reasonable process where designers report what needs to be done (functional requirements), how it can be done (design parameters), why it will work (analysis), who else has done similar work (references), and what are the risks and possible countermeasures. They also emphasize the importance of collaboration indicating that after individual work follows peer-review evaluation process (PREP), and then the team (3-5 people) brainstorms. However, Vasconcelos and Crilly (2016) argue that it is difficult to say whether the best results come from individuals working alone or from group work, or on what should the size of these groups be.

Goucher-Lambert and Cagan (2019) explore design works according to four criteria: feasibility, novelty, usefulness, and quality. All criteria are rated on an anchored scale from 0 (low) to 2 (high).

There are different approaches to the design process, but throughout the approaches, it is characteristic that it is seen as a creative process. We can see the design process as a non-linear process because in each step we can go back. For instance, in the production process, we might also generate new ideas for later use. Furthermore, the authors of this article believe that testing should be done already in the work process to prevent mistakes. Planning is an important step; however, it is emphasized but not singled out as a separate step in the existing subject. It is necessary to try 
different ways and find the most appropriate ones for learning design in general schools and universities for future Design and Technologies teachers in Latvia.

\section{Method}

Two types of structured diary forms were created. One was developed according to the approach proposed in the new standard and programs for the technology domain of general education in Latvia regarding the design process: identification of needs and opportunities, finding ideas and choosing a solution, planning, making, assessing, testing, developing, and implementing (Noteikumi par valsts pamatizglitîbas standartu un pamatizglitîbas programmu paraugiem, 2018). The diary form was offered to future primary school teachers to develop a product design of their choice. The form was filled by 28 future primary education teachers, and each student's diary had a unique code from S1 to S28 (one code for each student).

The second diary form was developed according to Freimane's (2005b) theory of the design process. It covers three components: preliminary research (definition of the problem, identifying needs and wants, developing the required tasks), research, sketching, identifying the skills to develop, establishing assessment criteria, analysis of the design process, sample, and final product assessment. This type of form was offered to future home economics and technologies teachers in four different textile craft and methodology courses. The empirical study was conducted at a time when the new design and technologies teachers' sub-program was still being developed. Therefore, the design process approach was implemented within the framework of home economics and technologies teachers' sub-program to try out and prepare for the new approach as well as prepare students to teach the new subject. The students were assigned to create and design a product in their relevant course of study: weaving, knitting, crochet, print, and batik. 12 forms were filled by 12 students, and each student's form had a unique code from MT1 to MT12 (one code for each student).

These diary forms were analyzed according to van Dooren and colleagues (2014) and the five generic elements of the design process they described: (1) experimenting or exploring and deciding, (2) guiding theme or qualities, (3) domains, (4) frame of reference or library, (5) laboratory or (visual) language - sketching and modelling. Each of these components had an accorded table with various columns including the main elements of these components. The coded responses were organized in rows, and each code was marked with a cross if the according respondent's diary included an element of the components. Altogether 5 tables were created according to van Dooren and colleagues' (2014) five generic elements of 
the design process. To assess the sketches, criteria and level descriptions made by Syrjäläinen and Seitamaa-Hakkarainen (2014) were used.

The pilot research in two student groups $(\mathrm{N} 1=28$; N2 $=12)$ was carried out between February 2019 and January 2020.

The method of content analysis of student diaries was used. The diaries were analyzed according to van Dooren and colleagues' (2014) theory of generic elements in the design process.

\section{Results}

\section{Experimenting: exploring and deciding}

The results show that the majority of future primary school teachers mention exploring, whereas significantly fewer students mention experimentation and decision-making. Mistakes along the process, which are characteristic of any creative process, are only mentioned by a few students.

The diaries sourced from home economics and technologies teachers show similar results. Exploring is mentioned in almost all diaries, decision-making is mentioned in half, and experimentation - less than half of the diaries. Only 3 students discuss difficulties in the process and mistakes, stating that the product's final result can be completely changed from the idea (see Table 1).

Table 1. Experimenting: exploring and deciding

\begin{tabular}{|c|c|c|c|c|c|c|c|c|c|c|c|c|c|}
\hline \multirow{2}{*}{\begin{tabular}{|l|} 
Criteria \\
Times \\
men- \\
tioned
\end{tabular}} & \multicolumn{3}{|c|}{$\begin{array}{l}\text { Experiment- } \\
\text { ing }\end{array}$} & \multicolumn{3}{|c|}{ Exploring } & \multicolumn{3}{|c|}{ Deciding } & \multicolumn{3}{|c|}{ Mistakes } & \multirow{2}{*}{\begin{tabular}{|l|}
$\begin{array}{l}\text { Changed } \\
\text { idea }\end{array}$ \\
$\begin{array}{l}\text { Number } \\
\text { of times }\end{array}$
\end{tabular}} \\
\hline & 0 & $1-2$ & $>2$ & 0 & $1-2$ & $>2$ & 0 & $1-2$ & $>2$ & 0 & $1-2$ & $>2$ & \\
\hline $\mathrm{N} 1=28$ & 19 & 8 & 1 & 2 & 25 & 1 & 17 & 11 & 0 & 22 & 6 & 0 & 3 \\
\hline $\mathrm{N} 2=12$ & 8 & 4 & 0 & 2 & 8 & 2 & 6 & 6 & 0 & 9 & 3 & 0 & 3 \\
\hline
\end{tabular}

\section{Guiding theme or qualities}

The first 7 columns were added before analyzing the diary forms, the names were given to the qualities as the research progressed. In all diaries, students of the primary education teacher program mentioned a guiding theme, 13 students identified it as singular, 5 topics were mentioned by 2-3 students. 3 students mentioned interior decorations, 3 students mentioned hand puppets, 3 mentioned toys, 2 gifts, and 2 - recycled material use. For instance, student S6 wrote that the guiding theme - the use of recycled materials - was determined by the materials available to her at home:

S6 Since there were already many different pieces of fabrics at home, I realized that I could make a sustainable blanket. 
The most popular evaluation criteria mentioned are the technical execution of the product (21 students), functionality (15), and creativity (13). 7 students mentioned color composition, 6 students mentioned the application of previous sketches, 4 students mentioned the visual outcome of the result as a criterion. Other criteria - the product's reflection in the theme, using different materials, presentation, etc., were mentioned by 3 or fewer students.

For example, when evaluating the manufactured bag, student S5 paid special attention to the quality of the technical performance:

S5 Evaluation criteria for assessment of the bag: The machine stitch is straight, the handles are sewn symmetrically and carefully, the textile mosaic is neatly sewn onto the fabric bag....

All diaries from home economics and technologies teachers mentioned the guiding theme. As an important criterion for quality, all 12 students mentioned the technical execution of the final product, almost as many mentioned color coordination (11) and the final result (10). Creativity was mentioned by 9 students, 7 students added functionality, 6 - application of previous sketches. The blend of materials, volume of work, and complexity were mentioned less. 2 students mentioned fitting in the timeframe given for the production as a quality criterion, and one student mentioned sustainability (see Table 2).

Table 2. Guiding theme and qualities

\begin{tabular}{|c|c|c|c|c|c|c|c|c|c|c|c|c|c|c|c|c|c|c|c|}
\hline & \multicolumn{3}{|c|}{$\begin{array}{l}\text { Guiding } \\
\text { theme } \\
\text { men- } \\
\text { tioned }\end{array}$} & \multicolumn{3}{|c|}{$\begin{array}{l}\text { Qualities } \\
\text { men- } \\
\text { tioned }\end{array}$} & \multicolumn{13}{|c|}{ Qualities mentioned } \\
\hline & 0 & $\stackrel{\sim}{\stackrel{1}{-}}$ & $\begin{array}{l}\sim \\
\Lambda\end{array}$ & 0 & $\stackrel{N}{\stackrel{1}{L}}$ & $\begin{array}{l}\sim \\
\wedge\end{array}$ & 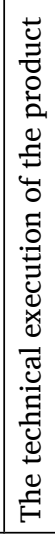 & 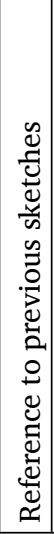 & 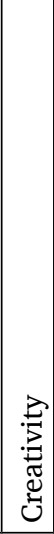 & 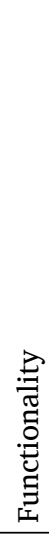 & 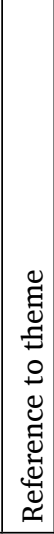 & 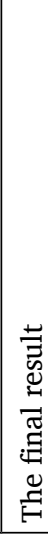 & 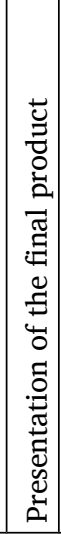 & 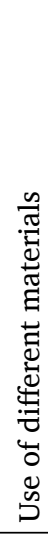 & 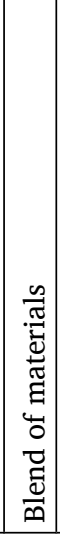 & 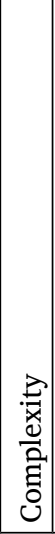 & 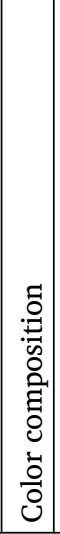 & 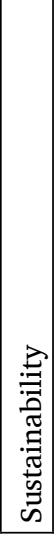 & 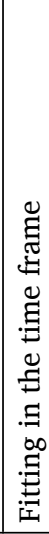 \\
\hline $\mathrm{N} 1=28$ & 0 & 1 & 27 & 0 & 11 & 17 & 21 & 6 & 13 & 15 & 3 & 4 & 2 & 2 & 1 & 1 & 7 & 2 & 0 \\
\hline $\mathrm{N} 2=12$ & 0 & 0 & 12 & 0 & 1 & 11 & 12 & 6 & 9 & 7 & 1 & 10 & 0 & 0 & 3 & 1 & 11 & 1 & 2 \\
\hline
\end{tabular}




\section{Domains}

Firstly, 5 main columns with 5 main domains were created: (1) form and space, (2) material (3) function, (4) physical context, and (5) social, cultural, historical, and philosophical context according to the research done by van Dooren and colleagues (2014). The number was increased during the research according to the content units discovered in the students' diaries. Each student has mentioned around 2-6 of the units. The most popular descriptive units of the primary school teachers are the use of materials (22), followed by color (11), three-dimensional form (9), and function (8). For instance, one of the students wrote in her diary that initially, she researched from what materials the products available in stores are made of; in this particular case, it was a mask:

S2 Choosing materials, exploring the material face masks are made of in stores.

Another student emphasized in her diary that the chosen material affects the quality of the product:

S9 Before starting a creative work, it is necessary to reflect and justify the choice of materials so that the work is of high quality and applicable.

I find out which materials, additional materials, and tools will be needed for the work.

Only three students directly mentioned cultural context, one of them including traditional Latvian culture and its context.

Home economics and technologies students chose material as the most defining characteristic unit (all 12 students), the next most popular unit is color (11), then the three-dimensionality and function (both 7). The texture is mentioned in the 6 diaries. 4 students mention traditional Latvian culture and its context (see Table 3 ).

Table 3. Domains

\begin{tabular}{|c|c|c|c|c|c|c|c|c|c|c|c|c|c|c|c|}
\hline 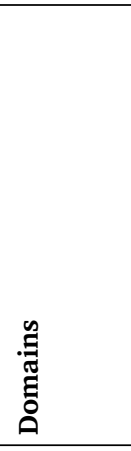 & $\frac{\grave{0}}{0}$ & 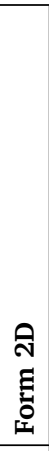 & 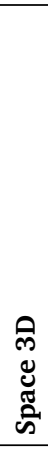 & $\begin{array}{l}\frac{\infty}{\pi} \\
\frac{\pi}{\pi} \\
\frac{\pi}{\pi}\end{array}$ & 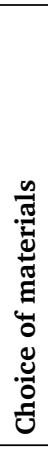 & 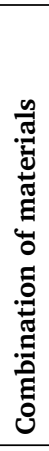 & 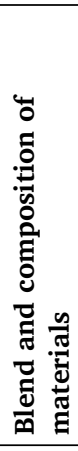 & 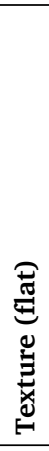 & 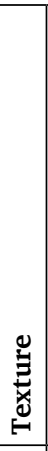 & $\underset{\Xi}{\stackrel{\Xi}{g}}$ & 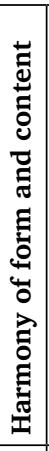 & 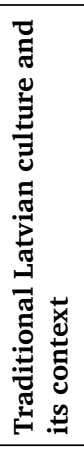 & 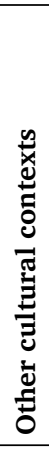 & 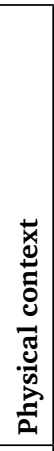 & 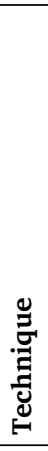 \\
\hline $\mathrm{N} 1=28$ & 11 & 2 & 9 & 22 & 9 & 6 & 3 & 1 & 0 & 8 & 2 & 1 & 2 & 2 & 5 \\
\hline $\mathrm{N} 2=12$ & 11 & 4 & 7 & 12 & 3 & 5 & 7 & 6 & 5 & 7 & 5 & 4 & 0 & 1 & 1 \\
\hline
\end{tabular}




\section{Use of various resources}

24 out of 28 primary school teachers noted that they had used one or more resources. Most students had used internet resources (17) and books (13), only 5 students had used magazines, 5 - video materials, and 1 used museum archives. Less than half -6 home economics and technologies students mentioned internet resources, only 3 had used books and 2 - magazines. One student mentioned researching and observing the professor's teaching aids (see Table 4).

Table 4. Use of various resources

\begin{tabular}{|l|l|l|c|c|c|c|c|}
\hline $\begin{array}{l}\text { Resourc- } \\
\text { es }\end{array}$ & $\begin{array}{l}\text { Not men- } \\
\text { tioned }\end{array}$ & $\begin{array}{l}\text { Internet } \\
\text { resources }\end{array}$ & Books & $\begin{array}{l}\text { Maga- } \\
\text { zines }\end{array}$ & Video & $\begin{array}{l}\text { Museum } \\
\text { archives }\end{array}$ & $\begin{array}{l}\text { Teaching } \\
\text { aids }\end{array}$ \\
\hline $\mathrm{N} 1=28$ & 4 & 17 & 13 & 5 & 5 & 1 & 0 \\
\hline $\mathrm{N} 2=12$ & 0 & 6 & 3 & 2 & 0 & 0 & 1 \\
\hline
\end{tabular}

\section{Sketching and modelling}

22 students of primary education mention drawing sketches. Only 10 students have enclosed the sketches in their diaries. 6 students have added one sketch, 1 student has added two sketches, two students have enclosed three, and one student - five sketches. One of the sketches is very detailed, well-explained, and includes sizing.

Most of the home economics and technologies students' diaries contain sketches (10), eight of them have 4-8 sketches, the rest have fewer. Mostly black and white with relative detail and form variety. Many have explanations in text, descriptions. Three sketches are colorful, one has very intricate details and form variants. One diary features a knitting pattern along with the sketches. See Table 5 and Fig. 1-2.

Table 5. Sketching

\begin{tabular}{|c|c|c|c|c|c|c|c|c|c|c|}
\hline & \multicolumn{4}{|c|}{ Number of the sketches } & \multicolumn{6}{|c|}{ Quality of the sketches } \\
\hline & 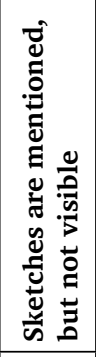 & $r$ & $\stackrel{?}{\stackrel{n}{N}}$ & $\begin{array}{l}\boldsymbol{\sigma} \\
\Lambda\end{array}$ & 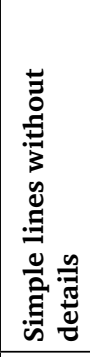 & 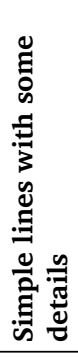 & 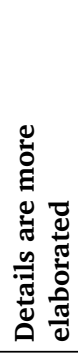 & 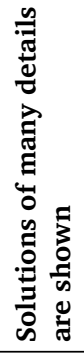 & 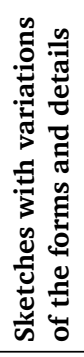 & 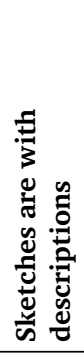 \\
\hline $\mathrm{N} 1=28$ & 12 & 6 & 3 & 1 & 3 & 3 & 3 & 0 & 1 & 1 \\
\hline $\mathrm{N} 2=12$ & 2 & 0 & 2 & 8 & 1 & 3 & 2 & 1 & 3 & 6 \\
\hline
\end{tabular}



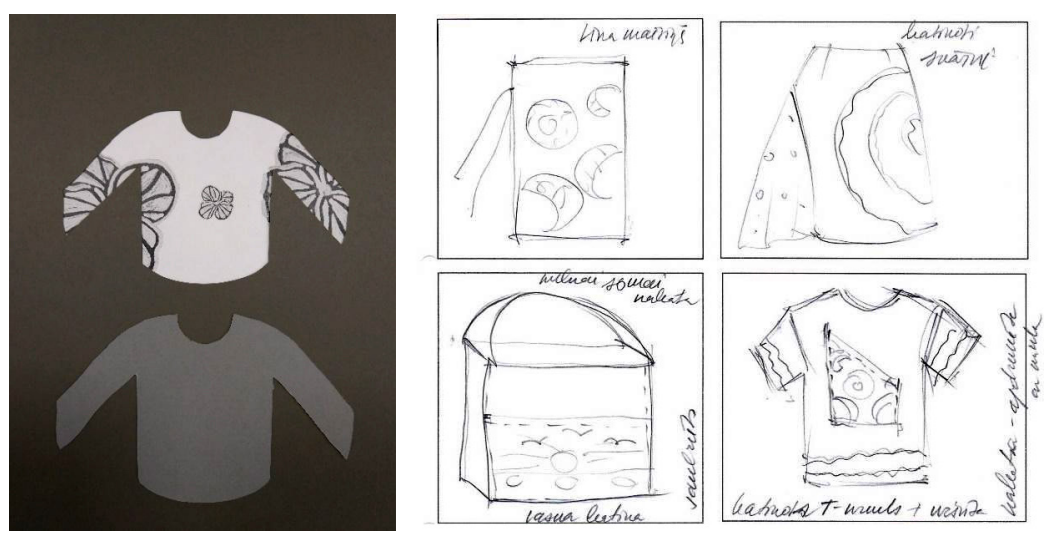

Figure 1-2. Sketch examples made by students M1 and M3

\section{Discussion}

When interpreting the results of the research, it should be taken into account that students do not have experience in documenting the design process, because so far, in the existing subject home economics and technologies it was not planned. Analyzing the students' diaries according to van Dooren and colleagues' (2014) 5 generic elements of the design process, it can be concluded that all students mentioned only 2 generic elements in the diaries: guiding theme or qualities and domains. Students of primary education could choose the theme themselves. The most popular guiding themes mentioned by three students of primary teachers were interior decorations, hand puppets, toys, two students' guiding theme was gifts and recycled material use. The main domain mentioned by both groups was material, then color and form, and space. The emphasis on the material and color can be understandable because for the products made by the students, textiles were mostly used as materials. There are a wide variety of textile materials, both in terms of origin and finish. In turn, the importance of form and space can be explained by the fact that the use of textiles allows creating a variety of forms: both two-dimensional and three-dimensional works.

The work was hampered by the fact that future primary school teachers study part-time and contact lessons were scheduled for specific groups of students for one day. In turn, home economics and technologies students study full-time. The study is also limited by the relatively small number of students.

In the future, it will be necessary to study how to promote the acquisition of students' skills in documenting the design process, assess the importance of experimentation, and seek to understand the meaning of sketches. 
Students should also learn not to be afraid of admitting mistakes. This means that in the future, the documentation of the design process should be continued, paying special attention to the rationale for documenting the design process in general, as well as experimentation, exploration and decision-making, use of various resources, and sketching and modeling, as not all students mentioned these generic elements. It would be necessary to develop more structured forms for documenting the design process, as well as to include the documentation of the design process as an evaluation criterion.

\section{Conclusions}

As the new reform is implemented in general education schools and teacher education, and there is the shift from home economics and technologies as a subject to design and technologies, more methods of teacher education and successful preparation must be researched. In their professional work, many teachers use the experience gained in school and university. In this case, such general education experience does not suffice, hence the need to ensure comprehension and research of the design process and methods of teaching it.

While researching home economics and technologies students' diaries, it can be concluded that greater attention needs to be paid to the documentation of the design process. Thus, the students practice using precise terminology, observing and defining all aspects related to the product creation and their significance. For example, the functionality of the product design was mentioned only in 7 of the diaries of the future home economics and technologies teachers, whereas real textile products were usable and fully functional.

It can also be concluded that greater attention should be paid to experimenting with materials, elements of techniques and techniques themselves, sketching, and detail. There should be various forms of design and versatile content research. Such evaluation criteria as a reference to original sketches, blend of materials, unity of composition should also be recognized as important. Regarding the resources, students' attention must be drawn to the research of real design and art pieces in museums, archives, and exhibitions.

\section{References}

Aflatoony, L., Wakkary, R., \& Hawryshkewich, A. (2018a). Characteristics of an effective secondary school design thinking curriculum. FormAkademisk - Research Journal of Design and Design Education, 11(5), 1-15. https://doi.org/10.7577/formakademisk.1626 
Aflatoony, L., Wakkary, R. \& Neustaedter, C. (2018b). Becoming a design thinker: Assessing the learning process of students in a secondary level design thinking course. The International Journal of Art \& Design Education, 37(3), 438-453. https://doi. org/10.1111/jade.12139

Bresciani, S. (2019). Visual design thinking: a collaborative dimensions framework to profile visualisations. Design Studies, 63, 92-124. https://doi.org/10.1016/j. destud.2019.04.001

Carroll, M., Goldman, S., Britos, L, Koh, J., Royalty, A., Hornstein, M. (2010). Destination, imagination and the fires within: Design thinking in a middle school classroom. International Journal of Art \& Design Education, 29(1), 37-53. https://doi. org/10.1111/j.1476-8070.2010.01632.x

Dazkir, S. S., Mower, J. M., Reddy-Best, K. L., \& Pedersen, E. L. (2013). An exploration of design students' inspiration process. College Student Journal, 47(2), 394-404. Retrieved from: http://datubazes.lanet.lv:2095/login.aspx?direct $=$ true\&db $=\mathrm{a} 9 \mathrm{~h} \& \mathrm{AN}=$ 88413470\&site $=$ ehost-live

Doorley, S., Holcomb, S., Klebahn, P., Segovia, K. \& Utley, J. (2018). Design thinking bootleg. Hasso Plattner Institute of Design at Stanford University. https://dschool. stanford.edu/resources/design-thinking-bootleg

Dorst, K., \& Cross, N. (2001) Creativity in the design process: Co-evolution of problemsolution. Design Studies, 22(5), 425-437. https://doi.org/10.1016/S0142-694X(01)00009-6

Findeli, A. (2001). Rethinking design education for the $21^{\text {st }}$ century: Theoretical, methodological, and ethical discussion. Design Issues, 17(1), 5-17. https://doi.org/10.1162/ 07479360152103796

Freimane, A. (2015a). Case study: Design thinking and new product development for school-age children. LearnXDesign, Chicago, USA.

Freimane, A. (2015b). Dizains ilgtspējīgai sociālai labklājỉbai. Dizaina paradigmas maina. [Design for sustainable social well-being. The paradigm shift of design.] Rīga: Mākslas Akadēmija. Promocijas darbs. [Doctoral thesis]

Goucher-Lambert, \& K., Cagan, J. (2019). Crowdsourcing inspiration: Using crowdgenerated inspirational stimuli to support designer ideation. Design Studies, 61, 1-29. https://doi.org/10.1016/j.destud.2019.01.001

Graham, M., Slocum, A., \& Moreno Sanchez, R. (2007). Teaching high school students and college freshmen product development by deterministic design with PREP. Journal of Mechanical Design, 129(7), 677-681. http://hdl.handle.net/1721.1/86389

Hasso Plattner Institute of Design at Stanford (2011). Design thinking bootcamp bootleg. https://dschool.stanford.edu/s/METHODCARDS-v3-slim.pdf

Hur, E., \& Beverley, K. (2013). The role of craft in a co-design system for sustainable fashion. In: Making Futures: The Crafts in the Context of Emerging Global Sustainability Agendas. Making Futures: the crafts as change maker in sustainably aware cultures, 15-16 September 2011, Dartington Estate, Devon, UK, 1-16.

James, M. (2017). Advancing design thinking towards a better understanding of self and others. FormAkademisk - Research Journal of Design and Design Education, 10(2), 1-14. https://doi.org/10.7577/formakademisk.1649

Laamanen, T.-K. (2012). Design learning in textiles teacher education main challenges. The 5th Intercultural Arts Education Conference: Procedia - Social and Behavioral Sciences, 45, 257-267 https://www.sciencedirect.com/ 
McLachlan, K., Laws, M., Unterholzner, S., Morgan, A., \& Herr, A. (n.d.). Engineering for good [Poster-12x18in-PRINT-2-reprint]. Retrieved from https://www.pbslearningmedia. org/collection/engineering-for-good/

Noteikumi par valsts pamatizglìtības standartu, pamatizglìtības mācību priekšmetu standartiem un pamatizglītības programmu paraugiem, Latvijas Republikas tiesību akti, Ministru kabineta noteikumi Nr. 468. (2014). [Regulations Regarding the State Standard in Basic Education, the Subjects of Study Standards in Basic Education and Model Basic Educational Programmes, Republic of Latvia Cabinet Regulation No. 468]. Retrieved from http://likumi.lv/doc.php?id $=268342$

Noteikumi par valsts pamatizglìtības standartu un pamatizglìtības programmu paraugiem, Latvijas Republikas tiesību akti, Ministru kabineta noteikumi Nr. 747. (2018). [Regulations Regarding the State Basic Education Standard and Model Basic Education Programmes, Republic of Latvia Cabinet Regulation No. 747]. Retrieved from https://likumi.lv/doc.php?id $=268342$

Porko-Hudd, M., Pöllänen, S., \& Lindfors, E. (2018). Common and holistic crafts education in Finland. Techne Series - Research in Sloyd Education and Craft Science A, 25(3), 26-38. https://journals.hioa.no/index.php/techneA/article/view/3025

Reitan, J. B. (2014). Learning by watching Vernacular Iñupiaq-Inuit design learning as inspiration for design education. Techne Series - Research in Sloyd Education and Craft Science A, 21(2), 1-20. https://journals.hioa.no/index.php/techneA/article/view/1263

Sawyer, R. K. (2018). Teaching and learning how to create in schools of art and design, Journal of the Learning Sciences, 27(1), 137-181. https://doi.org/ 10.1080/ 10508406.2017.1381963

Syrjäläinen, E., \& Seitamaa-Hakkarainen, p. (2014). The quality of design in $9^{\text {th }}$-grade pupils' design-and-make assignments in craft education. Design and Technology Education: An International Journal, 19(2), 30-39. http://ojs.lboro.ac.uk/ojs/index.php/DATE/ article/view/1931/197

Van Dooren, E., Boshuizen, E., van Merrienboer, J., Asselbergs, T., \& van Dorst, M. (2014). Making explicit in design education: generic elements in the design process. International Journal of Technology \& Design Education, 24, 53-71. https://doi.org/ 10.1007/s10798-013-9246-8

Vasconcelos, L. A., \& Crilly, N. (2016). Inspiration and fixation: Questions, methods, findings, and challenges. Design Studies, 42, 1-32. https://doi.org/10.1016/j.destud. 2015.11.001 